\title{
RANCANG BANGUN APLIKASI E-COMMERCE PADA TOKO ROTI ADZIDZAH
}

\author{
Eka Dian Ismawati, Taufik Rachman, Zaudah Cyly Arrum Dalu \\ Program Studi Teknik Informatika, STT Stikma Internasional Malang \\ ekadian.ismawati@gmail.com
}

\begin{abstract}
ABSTRAK
E-Commerce merupakan transaksi yang dilakukan secara online melalui internet dalam bentuk website. Para pengunjung web layanan e-commerce dapat melakukan pemesanan barang secara online dan dapat mencari informasi mengenai produk-produk perusahaan tanpa harus datang ke toko. Bagi perusahaan, layanan e-commerce dapat dijadikan sebagai media promosi untuk memasarkan produknya agar dikenal oleh masyarat luas. Kajian ini bertujuan untuk membangun sistem e-commerce pada Toko Roti ADZIDZAH. Sistem penjualan ini dikembangkan dengan menggunakan perangkat lunak Adobe Photoshop 7.0, XAMPP yang merupakan gabungan dari Apache Web Server, PHP, dan MySQL, dan browser Mozilla Firefox. Sistem e-commerce penjualan ini bekerja untuk dapat melakukan pemesanan dan penjualan secara online. Tujuan aplikasi ini adalah untuk memberikan kemudahan kepada pemilik Toko dalam penjualan dan pemasaran produknya. Serta memberikan kemudahan kepada para pelanggan dalam melakukan pemesanan dan pembilian produk. Untuk itulah Toko Roti ADZIDZAH akan menggunakan layanan e-commerce, melihat dari kondisi dan pemikiran yang ada maka penulis ingin melakukan penelitian dengan judul "Rancang Bangun Aplikasi E-commerce Pada Toko Roti Adzidzah".
\end{abstract}

Kata kunci : E-Commerce, Toko Roti, Pemasaran Online

\section{PENDAHULUAN}

Toko Roti Adzdizah merupakan salah satu industri menengah yang memproduksi sekaligus menjual berbagai macam jenis roti, mulai dari roti tawar hingga bermacam-macam roti manis bervarian rasa. Toko Roti Adzidzah beralamat di Jl. Sawojajar Gang V/No. 35 C RT. 06 RW. 01 Malang - Jawa Timur. Sejauh ini Toko Roti Adzidzah sudah memiliki jumlah pelanggan yang tidak sedikit dan tersebar di seluruh kota Malang maupun kabupaten Malang.

Berdasarkan hasil wawancara yang dilakukan kepada pemilik Toko Roti Adzidzah, proses jual beli selama ini masih dilakukan secara langsung atau kovensional, dimana pelanggan datang ke toko untuk melakukan pembelian dan pembayaran secara tunai sehingga tidak dapat memfasilitasi pelanggan yang tidak bisa datang langsung ke toko untuk melakukan transaksi. Beberapa pelanggan juga mengeluh sedikit kesulitan dalam menjangkau toko yang letaknya kurang strategis atau jauh dari pusat kota. Selama ini, Toko Roti Adzidzah masih menggunakan brosur yang dirasa kurang memberikan informasi yang detail mengenai produk yang ditawarkan kepada para pelanggan. Hal ini tidak menjadi masalah apabila tidak terjadi perubahan data mengenai produk yang ditawarkan, tetapi apabila terjadi perubahan data pada produk yang ditawarkan maka harus dilakukan proses pencetakan brosur baru sesuai dengan data informasi terbaru. Sehingga akan menyebabkan pengeluaran lebih untuk kegiatan tersebut. Penyebaran informasi produk lewat brosur juga kurang efektif karena jumlah brosur yang dicetak terbatas sehingga hanya kalangan pelanggan tertentu yang bisa mendapatkannya.

Saat ini Toko Roti Adzidzah berusaha memperhatikan kebutuhan pelanggan akan pentingnya kemudahan transaksi dan akses informasi produk mereka melalui internet. E-Commerce merupakan solusi untuk menerapkan strategi pemasaran dan pelayanan pelanggan di Toko Roti Adzidzah. ECommerce dapat memberikan informasi terbaru kepada semua pelanggan dengan jumlah yang tak terbatas.

Berdasarkan uraian di atas maka akan dibuat suatu aplikasi E-Commerce pada Toko Roti Adzidzah yang berbasis B2C (Business to Customer). ECommerce merupakan salah satu konsep yang sangat berkembang dalam dunia internet. Pengguna sistem ini bisa menguntungkan beberapa pihak, baik pihak pelanggan maupun pihak penjual. Konsep ECommerce menyediakan banyak kemudahan dan kelebihan jika dibandingkan dengan model belanja konvensional. Selain proses transaksi bisa lebih cepat, produk yang dijual dapat dipromosikan secara lengkap.

Pembangunan Aplikasi E-Commerce di Toko Roti Azizah dapat menjadi alternatif untuk menyelesaikan berbagai permasalahan tersebut guna mencapai efektifitas maupun efisiensi toko tersebut.

Aplikasi E-Commerce yang dibuat diharapkan dapat mempermudah transaksi, menjangkau banyak pelanggan, dan memberikan informasi yang lebih lengkap mengenai produk yang tersedia.

\section{TINJAUAN PUSTAKA}

\subsection{Rancang Bangun}

Menurut Hasan Alvin (2006:14) Rancang bangun adalah suatu istilah umum untuk membuat atau mendesain suatu objek dari awal pembuatan sampai akhir pembuatan.

Rancang bangun berawal dari kata desain yang artinya perancangan, rancang, desain, bangun. Sedangkan merancang artinya mengatur, mengerjakan 
atau melakukan sesuatu dan perancangan artinya proses, cara, perbuatan merancang. Dapat disimpulkan arti kata desain adalah proses, cara, perbuatan dengan mengatur segala sesuatu sebelum bertindak atau merancang.

\subsection{Rancang-Bangun Sistem (System Engineering) dan Analisa.}

Karena perangkat lunak selalu merupakan bagian dari suatu sistem yang besar, pada tahap ini dimulai dengan penentuan kebutuhan untuk semua unsurunsur sistem dan kemudian membagi menjadi beberapa subset dari kebutuhan ini yang salah satunya ke dalam perangkat lunak.

Gambaran sistem ini dibutuhkan apabila perangkat lunak harus berhubungan dengan unsurunsur lain seperti perangkat keras, orang-orang dan data base. Rancang-Bangun sistem dan analisa meliputi kebutuhan yang dikumpulkan pada tingkat sistem yang lebih rendah dari Top-Level desain dan analisa.

\subsection{Analisa Kebutuhan Perangkat Lunak.}

Proses pengumpulan kebutuhan diintesifkan dan secara khusus terpusat pada perangkat lunak. Untuk memahami sifat alamiah program dalam pembuatannya, software engineer ("analisis") harus memahami informasi tentang perangkat lunak, seperti halnya fungsi yang akan dijalankan dan kemampuannya. Kebutuhan dari sistem dan perangkat lunak didokumentasikandan ditinjau bersama dengan pelanggan.

\subsection{Disain}

Disain perangkat lunak benar-benar suatu proses yang mempunyai banyak tahapan yang berfokus pada 3 atribut program, yaitu : Struktur data, Arsitektur perangkat lunak dan Mengenai cara yang lebih mendetail. Proses disain menterjemahkan kebutuhan ke dalam suatu presentasi perangkat lunak yang dapat digunakan sebagai penilaian kualitas sebelum memulai pengkodean.

\subsection{Pengkodean (coding)}

Disain harus bisa diterjemahkan ke dalam suatu format yang terbaca oleh mesin. Langkah pengkodean yang dilaksanakan pada bagian ini. Jika disain dilakukan dalm suatu cara yang terperinci, pengkodean dapat terpenuhi secara mekanistik.

\subsection{Pengujian (testing)}

Tahap ini bisa dilakukan apabila prose pengkodean telah selesai. Proses pengujian memusatkan pada logika internal dari perangkat luank, meyakinkan bahwa semua statemen telah diuji, dan pada fungsional eksternal yaitu melaksanakan test untuk meyakinkan masukan yang digambarkan itu akan menghasilkan keluaran yang nyata yang disepakati sebagai hasil telah diminta.

\subsection{Pemeliharaan (maintenance)}

Perangkat lunak lambat laun niscaya akan mengalami perubahan setelah digunakan oleh pelanggan (suatu perkecualian mungkin penambahan perangkat lunak).

Perubahan akan terjadi bisa disebabkan oleh perangkat lunak menyesuaikan diri untuk mengakomodasi perubahan dalam lingkungan eksternalnya (misalnya, suatu perubahan diperlukanoleh karena sistem operasi atau perankat keras telah berbeda dan lebih maju), atau disebabkan oleh keperluan fungsional pelanggan atau peningkatan kemampuan software. Pemeliharaan perangkat lunak berlaku untuk semua tahapan dalam siklus kehidupan untuk program yang telah ada.

\subsection{Pengertian E-Commerce}

Internet Commerce atau Ecom atau E-Commerce atau Immerce yang pada dasarnya semua sebutan diatas mempunyai makna yang sama. Istilah-istilah tersebut berarti membeli atau menjual secara elektronik dan kegiatan ini dilakukan pada jaringan internet.

E-Commerce atau yang lebih dikenal dengan ecom dapat diartikan sebagai cara berbelanja atau berdagang secara online atau direct selling yang memanfaatkan fasilitas Internet di mana terdapat website yang dapat menyediakan layanan "get ang deliver". (Munawar: 2009).

David Baum menyatakan bahwa "E-Commerce is a dynamic set of technologies, applications, and business process that link enterprise, consumer, and communities through electronic transactions and the electronic exchange of goods, services, and information". E-Commerce merupakan satu set dinamis teknologi, aplikasi, dan proses bisnis yang menghubungkan perusahaan, konsumen, dan komunitas tertentu melalui transaksi elektronik dan perdagangan barang, pelayanan, dan informasi yang dilakukan secara elektronik. (Munawar: 2009)

Triton 2006, menjelaskan bahwa E-Commerce (Electronic Commerce) sebagai perdagangan elektronik dimana untuk transaksi perdagangan baik membeli maupun menjual dilakukan melalui elektronik pada jaringan Internet. Keberadaan ECommerce sendiri dalam Internet dapat dikenali melalui adanya fasilitas pemasangan iklan, penjualan, dan service support terbaik bagi seluruh pelanggannya dengan menggunakan sebuah toko online berbentuk web yang setiap harinya beroperasi selama 24 jam.

\section{METODE PENELITIAN}

\subsection{Analisis Sistem}

Analisis sistem dapat didefinisikan sebagai penguraian dari suatu sistem informasi yang utuhke dalam bagian-bagian komponennya dengan maksud untuk mengidentifikasikan dan mengevaluasi permasalahan-permasalahan, kesempatankesempatan, hambatan-hambatan yang terjadi dan 
kebutuhan-kebutuhan yang diharapkan sehingga dapat diusulkan perbaikan-perbaikannya.

\subsection{Analisis Masalah}

Ada beberapa permasalahan yang dihadapi didalam sistem yang sedang berjalan saat ini. Permasalahan-permasalahan tersebut diuraikan pada tabel berikut:

Tabel 1. Analisis Masalah

\begin{tabular}{|c|l|c|}
\hline No. & \multicolumn{1}{|c|}{ Permasalahan } & Bagian/Pihak \\
\hline 1. & $\begin{array}{l}\text { Sistem yang berjalan saat ini masih } \\
\text { kovensional dengan sistem transaksi } \\
\text { barang secara langsung sehingga } \\
\text { menghabiskan waktu dan biaya yang } \\
\text { cukup banyak. }\end{array}$ & Pelanggan \\
\hline 2. & $\begin{array}{l}\text { Tidak adanya media promosi toko } \\
\text { Roti Adzidzah }\end{array}$ & Perusahaan \\
\hline 3. & $\begin{array}{l}\text { Dengan sistem yang berjalan } \\
\text { sekarang, pemberian informasi kepada } \\
\text { pelanggan dirasakan kurang efektif } \\
\text { sehingga pelanggan belum tentu } \\
\text { mendapatkan informasi secara } \\
\text { lengkap. }\end{array}$ & Pelanggan \\
\hline 4. & $\begin{array}{l}\text { Sistem pembayaran yang digunakan } \\
\text { hanya uang tunai, sehinnga dirasakan } \\
\text { kurang fleksibel. Bagi pelanggan yang } \\
\text { ingin melakukan transaksi dalam } \\
\text { jumlah besar, harus membawa uang } \\
\text { tunai yang cukup besar. }\end{array}$ & Pelanggan \\
\hline 5. & $\begin{array}{l}\text { Selama ini pengarsipan dilakukan } \\
\text { dengan menggunkan kertas sehingga } \\
\text { mudah hilang dan membutuhkan } \\
\text { waktu lama untuk mencarinya. }\end{array}$ & Perusahaan \\
\hline
\end{tabular}

\subsection{Analisis Sistem yang Berjalan Saat Ini}

Sistem pembelian yang dilakukan oleh pelanggan Toko Roti Adzidzah saat ini adalah sistem pembelian konvensional yaitu :

1. Pelanggan harus dating langsung ke toko tersebut.

2. Pelanggan memilih produk secara langsung.

3. Pelanggan melakukan negosiasi dengan penjual. Kemudian apabila sudah ada kesepakatan Pelanggan akan melakukan pembayaran secara tunai.

Hal ini sudah pasti menghabiskan banyak waktu dan biaya. Lebih jelasnya akan terlihat pada flow map berikut :

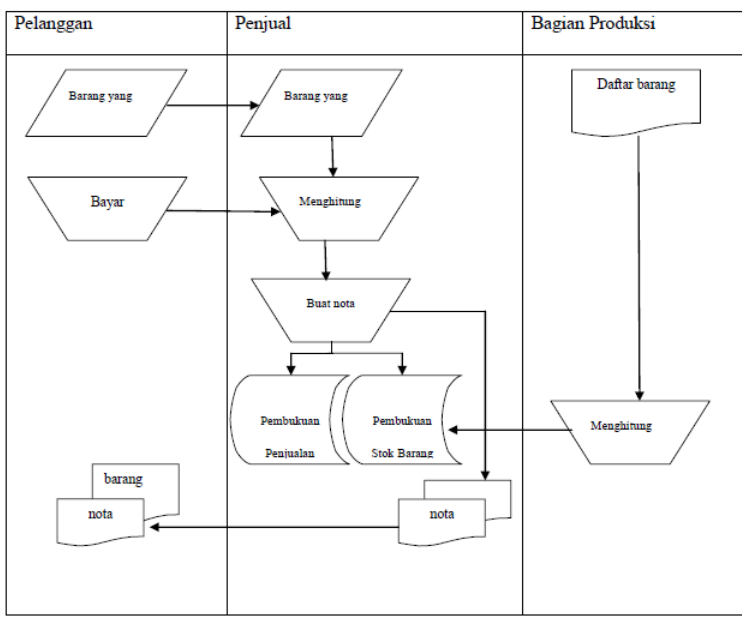

Gambar 1. Flow-map Penjualan Sekarang

\subsection{Solusi yang ditawarkan}

Dari permasalahan-permasalahan yang telah dijabarkan diatas, solusi yang penulis tawarkan adalah pembuatan e-commerce Toko Roti Adzidzah. Penulis berencana untuk membuat sistem promosi dan penjualan secara online.

Dalam sistem ini, pelanggan dapat melihat informasi barang dan dapat melakukan pemesanan secara online. Dengan sistem ini juga dapat menyelesaikan permasalahan promosi.

\subsection{Diagram Level Context}

Dalam perancangan sistem ini, penulis mencoba untuk memberikan gambaran mengenai alur arus data dari site mini, khususnya mengenai alur pemesanan produk. Adapun rancangan DFD pada sistem ini adalah sebagai berikut :

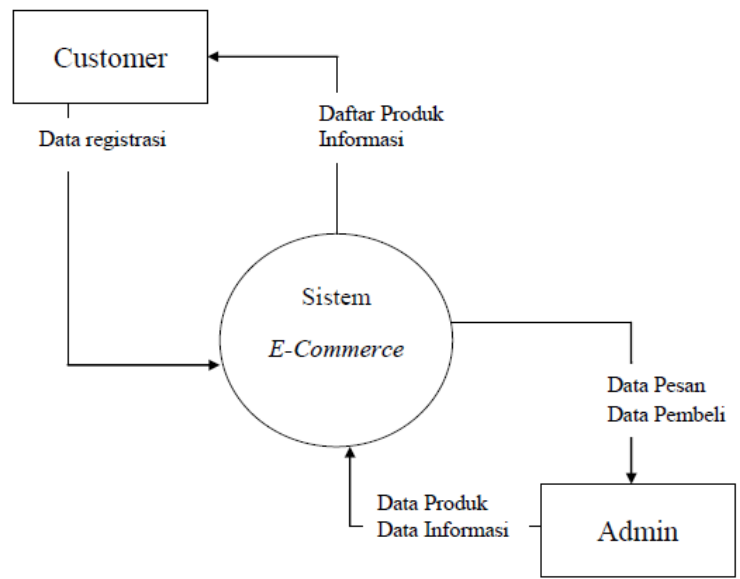

Gambar 2. Diagram Level Context 


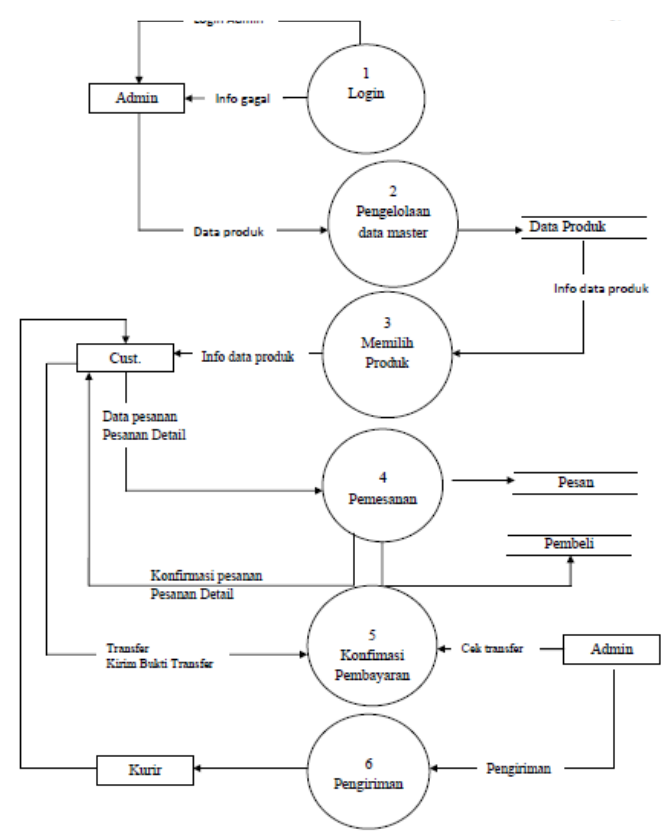

Gambar 3. Data Flow Diagram level 0

\section{HASIL DAN PEMBAHASAN}

\subsection{Struktur Menu}

Sistem ini dirancang dengan struktur menu utama sebagai berikut :

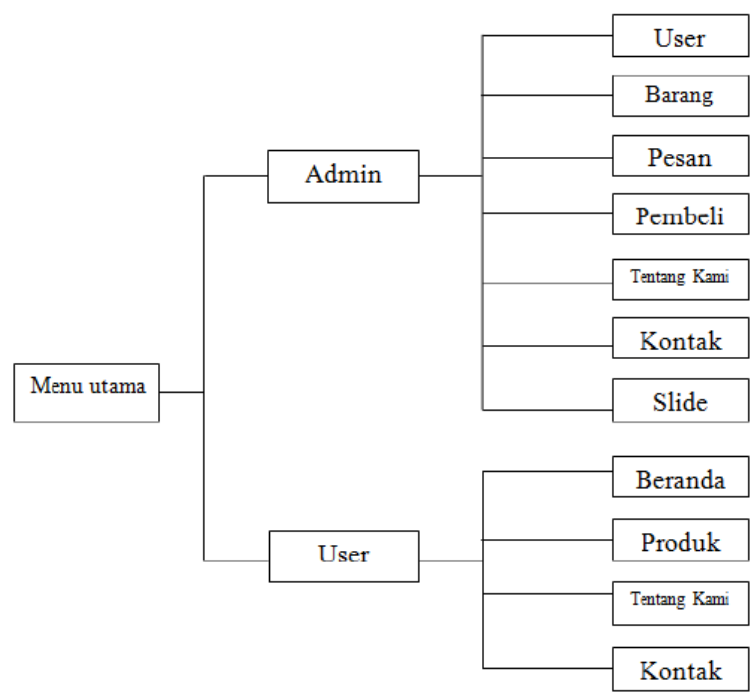

Gambar 4. Struktur Menu

\subsection{Halaman Utama}

Halaman ini merupakan beranda dari situs web, beranda situs web Toko Roti Adzidzah terdiri atas menu Beranda, Produk, Tentang kami, Kontak dan banner agar tampilan halaman web lebih menarik.

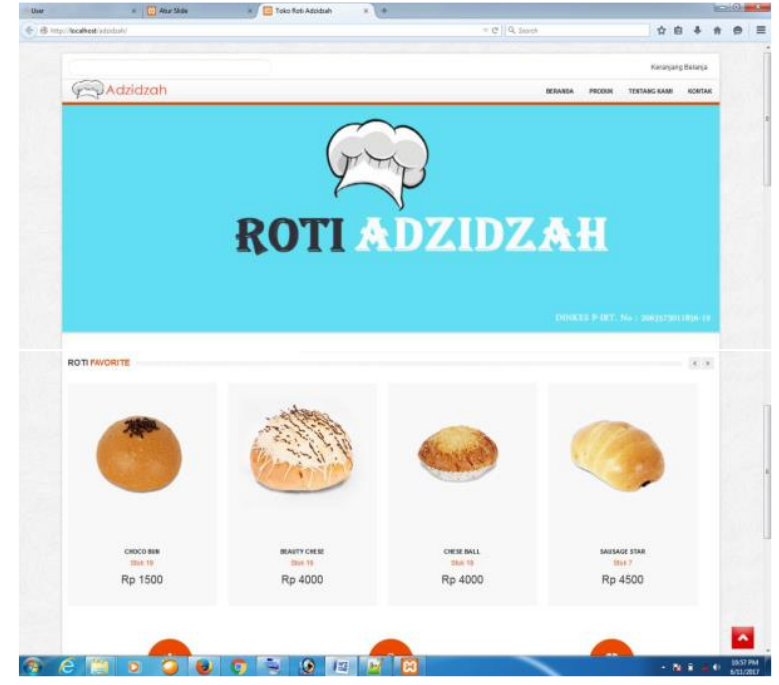

Gambar 5. Tampilan Halaman Beranda

\subsection{Halaman Produk}

Halaman produk ini menampilan semua produk roti yang tersedia di Toko Roti Adzidzah

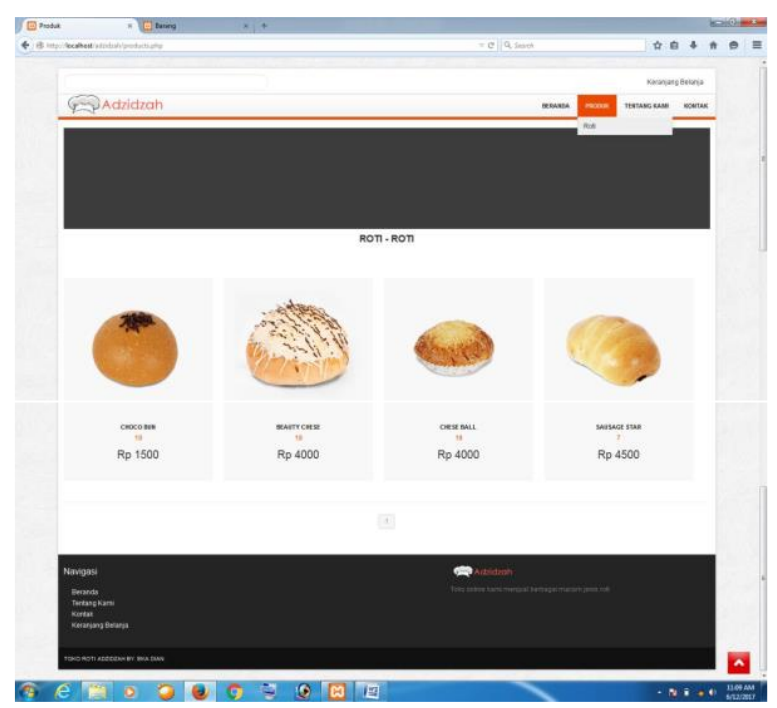

Gambar 6. Tampilan Halaman Produk

\subsection{Halaman Pelanggan}

Halaman ini merupakan fasilitas E-Commerce yang disediakan bagi para pengunjung situs untuk berbelanja. Tahap pembelian dimulai dari mengklik roti yang akan dibeli, kemudian akan tampil detail produk yang akan dibeli. Dari halaman ini, pembeli dapat menambah atau mengurangi jumlah roti yang akan dibeli. Kemudian, pembeli melakukkan check out untuk mengisi formulir data pembeli, dan selanjutnya menunggu konfirmasi dari admin ke nomor telepon masing-masing. 


\subsection{Halaman Keranjang Belanja}

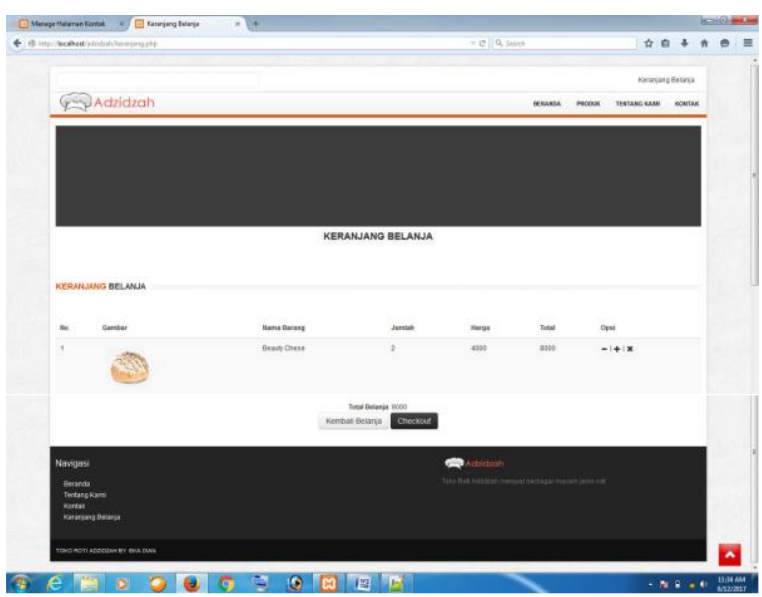

Gambar 6. Halaman Keranjang Belanja

\subsection{Check Out}

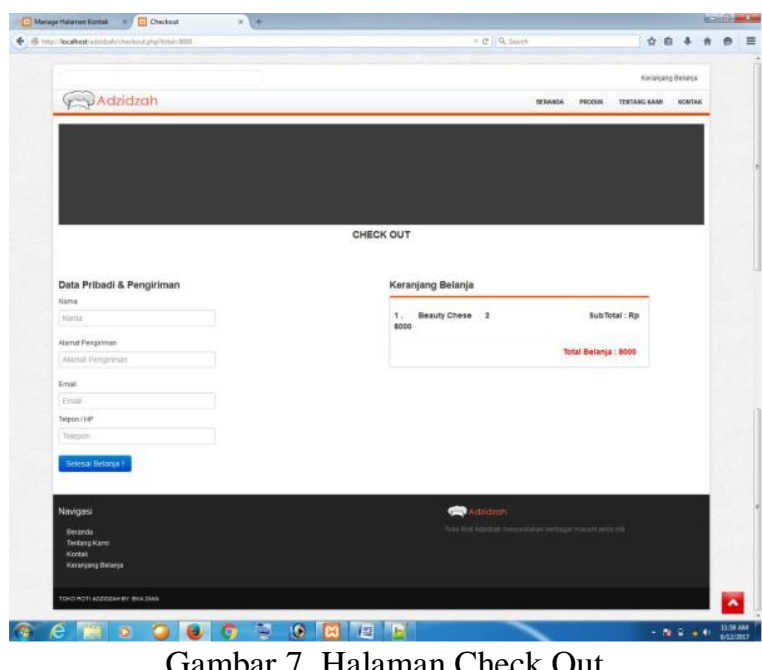

4.7. Halaman Daftar Transaksi atau Pembelian

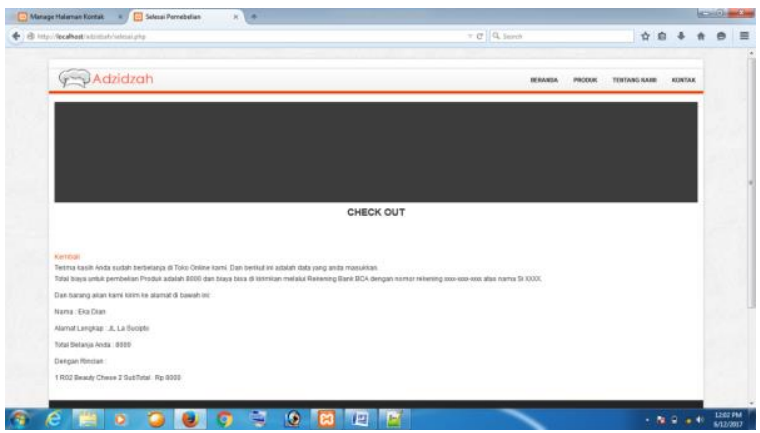

Gambar 8. Halaman Daftar Pembelian

\subsection{Halaman Daftar Barang}

Menu ini digunakan untuk mengedit, menambah, dan menghapus data produk

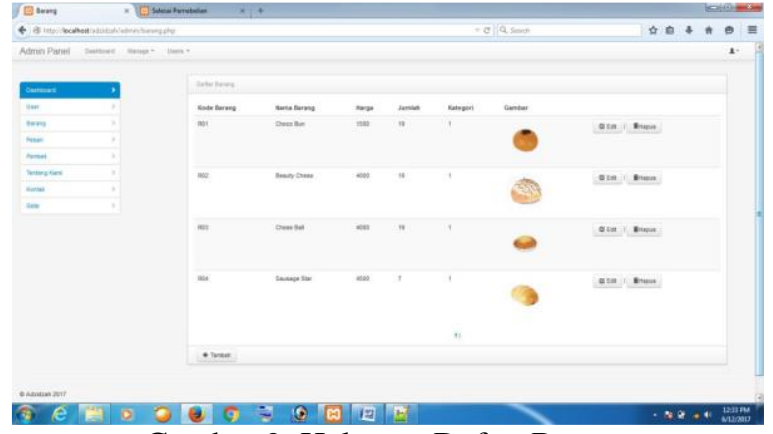

Gambar 9. Halaman Daftar Barang

\subsection{Halaman Daftar Pesan}

Menu ini berisi daftar pesanan dari pelanggan

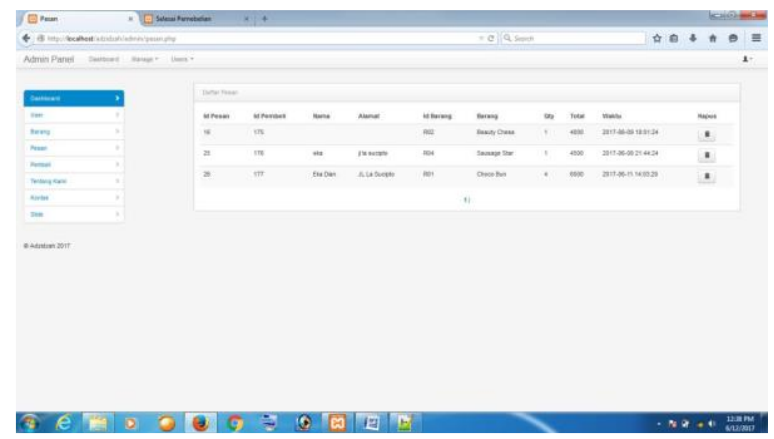

Gambar 10. Halaman Daftar Pesan

\section{KESIMPULAN DAN SARAN}

\subsection{Kesimpulan}

Berdasarkan uraian dari bab-bab di atas, dapat ditarik kesimpulan bahwa :

1. E-Commerce merupakan sistem transaksi jual beli yang terjadi lewat jalur elektronik yang dilakukan secara online dengan memanfaatkan jaringan internet.

2. Dengan memanfaatkan sistem e-commerce, seorang pemilik toko atau pengusaha dapat memperoleh beberapa keuntungan. Keuntungan tersebut antara lain dapat menemukan partner bisnis baru, meningkatkan produktivitas, akses informasi menjadi cepat, produk dapat tersebar secara lebih luas, serta meminimkan penggunaan kertas.

3. Aplikasi berbasis web dapat menjadi alternative pilihan utama bagi para user yang tidak ingin bersusah payah dalam mencari barang, yang dapat menghabiskan waktu, tenaga, dan uang.

4. Perancangan e-commerce harus dilakukan sebaik mungkin untuk menarik perhatian konsumen, dan menumbuhkan rasa percaya konsumen terhadap sistem e-commerce yang dimiliki suatu toko.

\subsection{Saran}

Dengan adanya penelitian ini, diharapkan adanya perbaikan maupun perubahan yang terjadi, baik itu untuk sistemnya maupun yang lainnya diharapkan dapat membantu mendukung perkembangan dan 
kemajuan perusahaan atau Toko Roti, khususnya Toko Roti Adzidzah.

Untuk menciptakan suatu perkembangan pemasaran dan penjualan yang lebih baik, maka semua pihak bisa memberikan masukkan atau saran demi tercapainya suatu keadaan yang diharapkan. Untuk itu, penulis memberikan beberapa saran dari penelitian yang telah dilakukan diantaranya adalah sebagai berikut :

1. Web ini masih mempunyai beberapa kekurangan seperti tidak dapat melakukan pembayaran melalui bank online. Oleh karena itu diharapkan web ini dapat dikembangkan lebih lanjut sehingga kekurangan-kekurangan di atas dapat diatasi. Juga diharapkan dapat dikembangkan dengan bahasa pemrograman lain yang mempunyai kemampuan lebih baik disbanding bahasa pemrograman PHP.

2. Perangkat lunak ini diharapkan dapat dijadikan motivasi bagi perusahaan lain yang ingin melakukan perubahan untuk perusahaannya, diharapkan untuk peneliti yang akan dating aplikasi berbasis web ini dapat dikembangkan lebih baik lagi, pada pemesanan barang diharapkan dapat lebih komunikatif dengan pemakai.

3. Bagi peneliti yang akan dating, di dalam penyempurnaan penelitian ini maka yang harus diperhatikan penambahan menu yang memungkinkan pelanggan melakukan pembayaran dengan menggunakan kartu kredit, sehingga pelanggan tidak perlu susah-susah melakukan transfer antar bank atau juga menu lainnya yang bersifat inovatif.

\section{DAFTAR PUSTAKA}

[1] Istilah Umum Untuk Membuat atau Mendesain Suatu Objek Dari Awal Pembuatan Sampai Akhir Pembuata,. Yogyakarta, Pusat Media.

[2] Munawar, 2009, Berdagang Secara Online Atau Direct selling "Get And Deliver", Gava Media, Yogyakarta.

[3] Nugroho, B, 2007, Membuat Sistem Informasi Penjualan Berbasis Web dengan PHP dan MySQL, Yogyakarta, GAVA MEDIA.

[4] Rexnowati, 2015. "Perancangan Sistem Informasi E-Commerce Pada Youlanda Bakery \& Cake shop". Skripsi, STIMIK TIME, Medan.

[5] Sunarto, Andi. 2009. Seluk Beluk E-Commerce, Garailmu, Yogyakarta.

[6] Sianipar, R.H. 2015, Membangun Web dengan PHP \& MySQL untuk Pemula dan Programmer, Informatika Bandung, Bandung.

[7] Utomo, eko Priyo. 2005. Berbisnis di Era Internet dengan E-Commerce, Yrama Widia, Bandung. 